\title{
地下水流動および海陸風を考慮した ウトナイ湖の水質拡散特性について
}

\author{
DYNAMIC CHARACTERISTICS OF WATER QUALITY \\ IN LAKE UTONAI, JAPAN \\ CONSIDERING EFFECTS OF GROUNDWATER FLOW AND SEA-LAND WIND
}

\author{
竹村 健 $^{1} \cdot$ 長谷川 覚也 $2 \cdot$ 長谷川 裕史 ${ }^{3} \cdot$ 藤間 聡 4 \\ Takeshi TAKEMURA, Kakuya HASEGAWA, Hiroshi HASEGAWA and Satoshi TOHMA \\ 1 正会員 株式会社ドーコン 河川部（０004-8585 札幌市厚別区厚別中央 1 条 5 丁目 4 番 1 号） \\ 2 正会員 工修 株式会社ドーコン 河川部（T004-8585 札幌市厚別区厚別中央 1 条 5 丁目 4 番 1 号) \\ 3 正会員 株式会社ドーコン 河川部（０04-8585 札幌市厚別区厚別中央 1 条 5 丁目 4 番 1 号) \\ 4 フェロー会員 工博 室蘭工業大学工学部 建設システム工学科（テ050-8585 室蘭市水元町 27 番 1 号）
}

\begin{abstract}
The area of this study, Lake Utonai, is in eastern Tomakomai, Hokkaido, Japan. In recent years, the lake has been experiencing the ecological eutrophication resulted from nutrient salts and fine sediments from the rivers, which will damage the ecosystem. The lake water is affected by sea-land wind from costal regions, and by groundwater flow, due to the lake's shallow depth. This study proposed a water quality model and a water flow model for the shallow lake, considering effects of groundwater flow and sea-land wind.
\end{abstract}

Key Words : Lake Utonai, groundwater flow, sea-land wind

\section{1.はじめに}

ウトナイ湖を含む湿原地域は, 図-1に示す北海道苫小 牧市東部に位置し、ラムサール条約に登録(1991 年されれ た自然保護区域である.しかしながら，近年美々川やウ トナイ湖周辺では, 住宅地, 農地開発, ゴルフ場に代表 されるリゾート開発，新空港建設など高度に土地利用が 進み，栄養塩や微細土砂の流入による生態系への影響が 䯚念されている.

本研究は，ウトナイ湖における環境保全対策の客観的 評価法の確立を目的として，物質移動の定量表現を可能 とする地下水流動を取り込んだ精度の高い水質拡散モデ ルを構築した. 本モデルの活用法としては、水質悪化要 因の分析及び污濁源対策や樹林帯等による負荷軽減効果 の定量化が可能になると考えている.

ウトナイ湖は, 湖自体が湿原の一部であり, 湖内の流 れが湿原域における地下水の影響を強く受ける浅水湖で ある. このため, 従来の湖のみを扱うモデルによる湖流 解析に, 湖岸境界部での地下水流の影響をいかに取り込 むかが課題であった.

本論文は, 長谷川らが行った地下水流動解析 ${ }^{1)}$ を含む

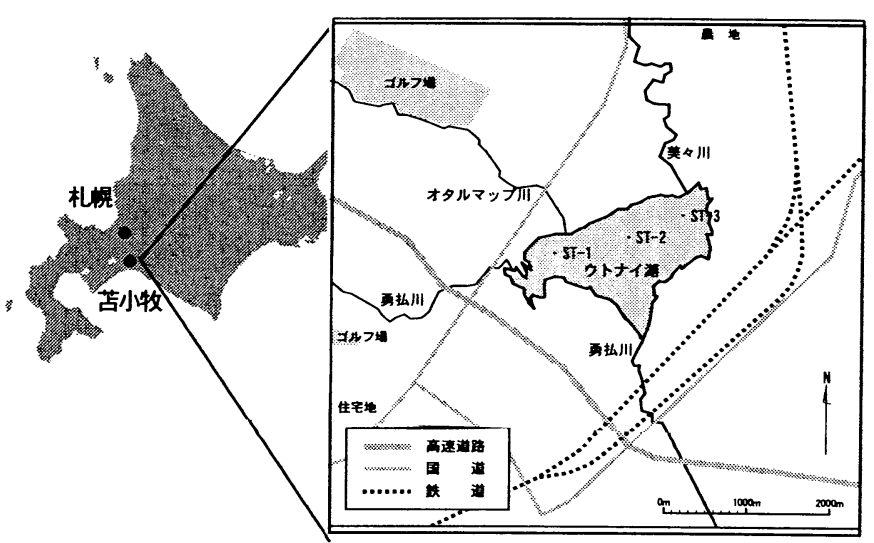

図-1 ウトナイ湖の位置

ウトナイ湖内の流れの解析モデルを基礎とし, 平成 12 年調査による境界条件（地下水位, 風向, 風速, 河川の 流入量の観測值）を用い, 再現計算を実施した. その結 果, 全ての境界条件を取り込んだ解析結果が最も再現性 が高い結果となり, 地下水流動についてもその透水量が 概小再現されていることを確認した. また，検証を行っ た地下水流動モデル及び湖流解析モデルに水質拡散モデ ルを取り込むことで, 湖内における水質拡散を再現し, 水質予測シミュレーションを実施した。 


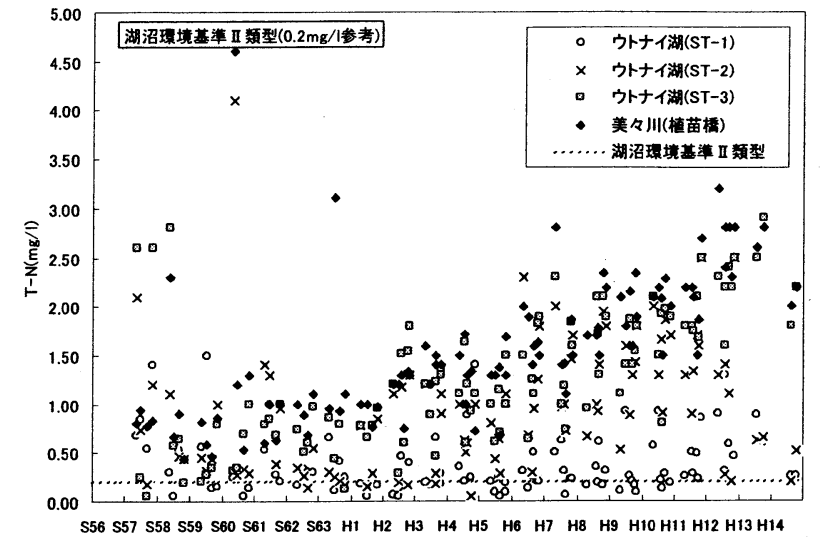

図-2 $\quad T-N$ 経年変化

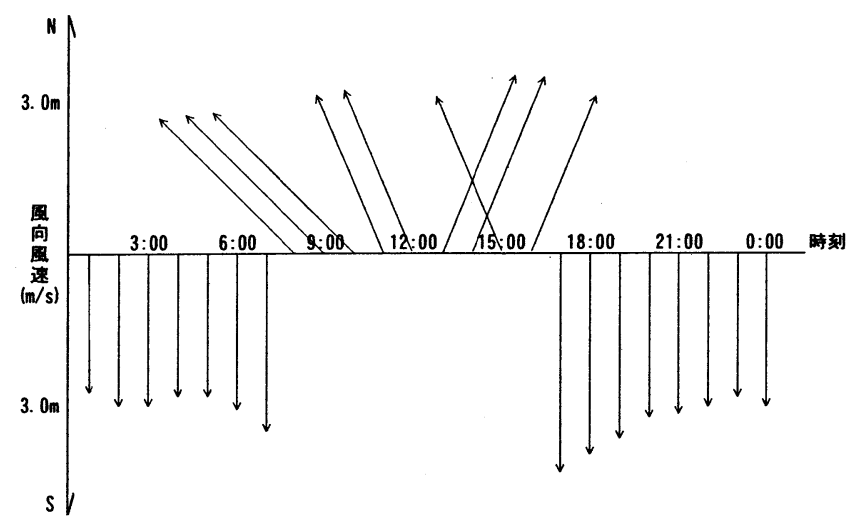

図-3 毎正時最頻風向 (苫小牧測候所)

\section{2. ウトナイ湖を含む湿原域の特性}

ウトナイ湖は図-1 に示すとおり，流域面積は約 117 $\mathrm{km}^{2}$, 東西長約 $2.8 \mathrm{~km}$, 南北長約 $1.8 \mathrm{~km}$, 湖水面積約 $2.4 \mathrm{~km}^{2}$, 湖水容量約 100 万 $\mathrm{m}^{3}$ の海跡湖で流入河川は美々川, 雷 払川，オタルマップ川，流出河川は勇払川である.

ウトナイ湖における湖流・水質拡散特性を考える上で 必要となる地下水, 海陸風, 流入出河川及びウトナイ湖 の水温・水質について概説する.

\section{(1) 地下水}

ウトナイ湖周辺の地形は，北側に長沼低地，西側に野 幌丘陵，東側に馬追丘陵があり，ウトナイ湖は勇払低地 に位置している.

地質状況は, 恵庭・樽前降下軽石層が分布し, その下 層に支笏火山噴出物層が分布している. なお, 樽前降下 軽石層は透水係数が非常に高いことが知られている.

美々川流域やウトナイ湖周辺の湿原域とそこに形成さ れる自然環境は，主として支笏火山噴出物層を帯水層と した地下水により維持されている. しかし, 図-2に示す とおり近年において特に美々川の水質污染が顕著であり, ウトナイ湖の富栄養化や湿原域における地下水污染の懸 念がある.

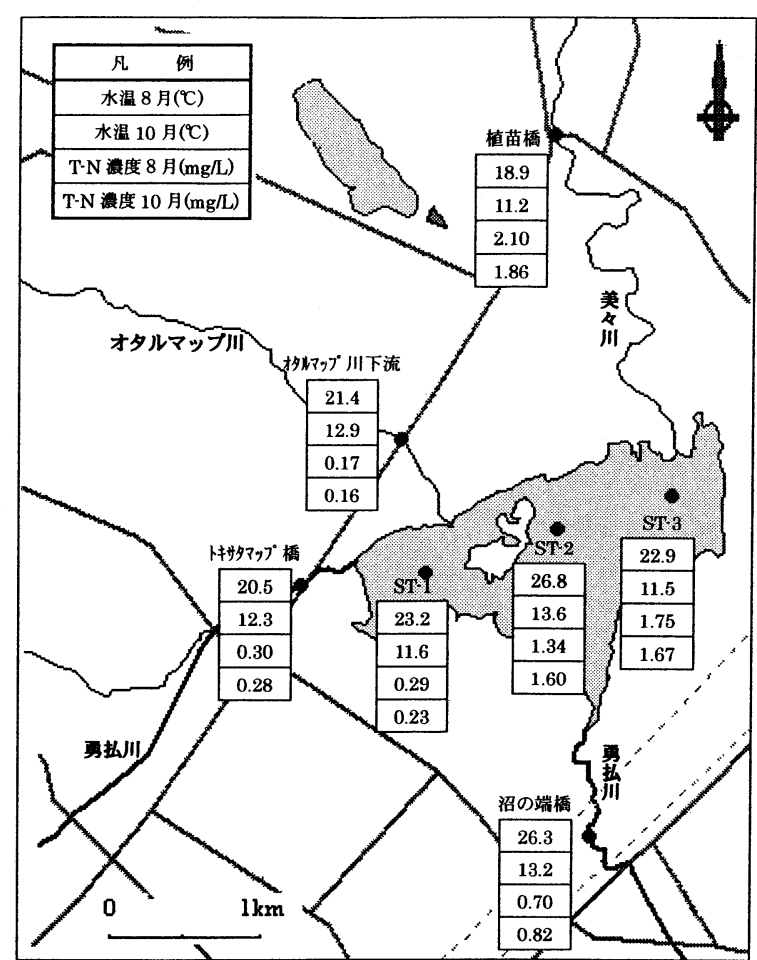

図-4 水温・水質の状況 (平成 11 年 8 月, 10 月)

\section{(2) 海陸風}

水深 $1 \mathrm{~m}$ 程度の浅水湖であるウトナイ湖は, 海岸から内 陸側に直線距離で約 $5 \mathrm{~km}$ に位置し, また, 海岸からウト ナイ湖までは低平地が続くため, 海と陸の熱容量の違い により発生する海陸風が卓越しやすく，湖流にも影響を 及ぼしていると考えられる. ウトナイ湖が結水する冬期 間を除く 4 月〜 11 月までの期間において, 近傍の苫小牧 測候所における 1992 2001 年の過去 10 年間の毎正時最 頻風向を整理した結果を図-3に示す. 夜間は陸風, 昼間 は海風の発生頻度が高く, 海陸風が卓越していることを 確認した.

\section{(3) 流入出河川及びウトナイ湖の水温・水質}

水温については, 図-4のとおり流入出河川と湖内の水 温差がわずかであることから, 解析は水温一定の条件と した.

美々川における T-N 濃度は年々増加傾向にあり，その 数值は非常に高く，またウトナイ湖においても美々川流 入部付近で増加傾向にある. 今回の水質拹散予測シミュ レーションでは, 美々川合流部にある濃度のトレーサを 与えて, 湖内での濃度変化を確認する.

\section{3. 地下水流動解析}

ウトナイ湖および美々川の涵養は地下水（TP で概ね $2 \mathrm{~m} \sim 10 \mathrm{~m}$ ）が主であり, 地下水の流入流出が湖流に与え る影響が大であることから, 当該区域の水質拡散を正確 に推定するには地下水の影響を考慮する必要がある. 
表-1 地下水流動解析諸元

\begin{tabular}{|l|l|}
\hline \multicolumn{1}{|c|}{ 項 目 } & \multicolumn{1}{c|}{ 使用データ } \\
\hline 平均地下水位 $m$ & 平成 8年 1月 1日 12月 31 日 \\
\hline 地下水位 $h$ & 平成 8年 8月 1日 8 月 31 日 \\
\hline 解析領域 & $12 \mathrm{~km} \times 12 \mathrm{~km}\left(144 \mathrm{~km}^{2}\right)$ \\
\hline 観測井数 $N$ & 27 地点 \\
\hline
\end{tabular}

本研究では, ウトナイ湖近傍域の地下水流量ベクトル の把握およびウトナイ湖への平均的な地下水流入 ・ 流出 量を予測するため, ウトナイ湖及びその周辺域を対象と した地下水流動解析を行った. 解析諸元を表-1 に示す.

\section{(1) モデル基礎式}

本解析モデルは, 必要とする情報が複数地点の観測地 下水位 $\boldsymbol{h}$ のみと極めて少ない資料より地下水流量ベクト ルの平面分布を予測できる点が特徽的である.

任意地点の地下水位 $\boldsymbol{h}$ は, 観測期間における平均値 $\boldsymbol{m}$ と変動成分 $z$ の和として(1)式で表す. 平均値 $m$ は, 領域 内で空間分布を有するとして平面位置座標 $x, y$ の多項式 (2)式による空間トレンドとして近似する. 変動成分 $z$ は, クリギング 2) と呼ばれる(3)式の線形回帰式より推定する. 同回帰式における重み保数 $\lambda_{0}^{i}$ は, (4)式および(5)式から推 定する. (4)式における $\gamma(d)$ は, 二点間における状態変数 の差の分散を定義する指標であり, バリオグラムと呼ば れる. 以上により地下水位 $h$ の空間分布を決定する.

$$
\begin{gathered}
h(x, y, t)=m(x, y)+z(x, y, t) \\
m(x, y)=a_{0}+a_{1} x+a_{2} y+a_{3} x^{2}+a_{4} x y+a_{5} y^{2}+ \\
\cdots+a_{k-2} x^{2} y^{n-2}+a_{k-1} x y^{n-1}+a_{k} y^{n} \\
z^{*}\left(X_{0}\right)=\sum_{i=1}^{N} \lambda_{0}^{i} z\left(X_{i}\right) \\
\gamma(d)=\frac{1}{2 N(d)} \sum_{i=1}^{N}\left[z\left(X_{i}+d\right)-z\left(X_{i}\right)\right]^{2} \\
\sum_{i=1}^{N} \lambda_{0}^{i} \gamma\left(X_{i}-X_{j}\right)+\mu=\gamma\left(X_{i}-X_{0}\right) \\
\sum_{i=1}^{N} \lambda_{0}^{i}=1 \quad(j=1, \cdots, N)
\end{gathered}
$$

ここに, $x, y$ : 平面位置座標, $t:$ 時間, $a$ : トレンド 多項式の係数, $k$ : トレンド項数, $n$ : 多項式の次数, $z^{*}\left(X_{0}\right)$ : 非観測地点 $X_{0}$ における地下水位推定値, $z\left(X_{i}\right)$ : 観測地点 $X_{i}$ における地下水位観測值, $\lambda_{0}^{i}: z\left(X_{i}\right)$ の重み倸 数, $\gamma(d)$ : バリオグラム, $z\left(X_{i}\right)$ : 観測地点 $X_{i}$ における 地下水位, $d$ : 地下水位観測点からの距離, $N(d)$ : 観測 点数を示す.

透水量係数の空間分布は, (1)式で得られた地下水位 $h$ より, 次式で示す平面二次元定常地下水流動方程式から 推定する.

$$
\frac{\partial}{\partial x}\left(T(x, y) \frac{\partial h}{\partial x}\right)+\frac{\partial}{\partial y}\left(T(x, y) \frac{\partial h}{\partial y}\right)+Q(x, y)=0
$$

表2 理論バリオグラム定式化

\begin{tabular}{|l|l|}
\hline \multicolumn{1}{|c|}{ 項 目 } & \multicolumn{1}{c|}{ 解析結果 } \\
\hline 階級 & $1000 \mathrm{~m}$ 刻み \\
\hline 適用半径 & $3100 \mathrm{~m}$ 以内 \\
\hline 理論バリオグラム & $\gamma(d)=2.31 \times 10^{-7} d+7.41 \times 10^{4}$ \\
\hline
\end{tabular}

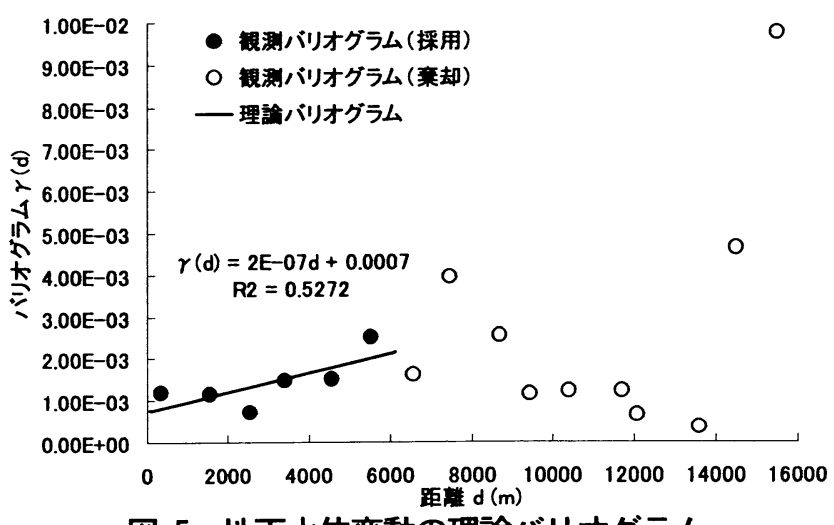

図-5 地下水位変動の理論バリオグラム

ここに, $h(x, y)$ は地下水位, $T(x, y)$ は透水量倸数, $Q(x, y)$ はかん養量や揚水量を示す。

\section{(2) 流量ベクトル平面分布の推定 \\ a) 解析条件}

地下水流動解析の解析対象領域は, ウトナイ湖を含む その周辺域 $12 \mathrm{~km} \times 12 \mathrm{~km}$ とした. 地下水位は十分な資料 が存在する平成 8 年調查結果を採用し, 平均地下水位 $m$ は 1 月 1 日〜 12 月 31 日の 1 年間の観測デー夕, 地下水 位 $h$ は 8 月 1 日〜 8 月 31 日の平均值を使用した.

b) 地下水位 $h$ の平面分布の推定

平均地下水位 $m$ は, 観測値之の残差平方和, $A I C^{3)}$ (赤 池情報量基準) 及び流域状況との適合性から多項式(2)で 示すトレンド次数 $n$ を 4 次として, 各係数 $a_{i}$ を決定する ことにより推定した.

地下水位変動量 $z$ は, 観測バリオグラム值を求めるた め観測点間の距離を $1000 \mathrm{~m}$ 刻みで階級分けを行う. 得ら れたバリオグラムの結果を表-2 および図-5に示す. 同図 から距離約 $6200 \mathrm{~m}$ まで理論バリオグラムは線形を有し ていることが認められる. したがって, 推定する地点か ら半径 $3100 \mathrm{~m}$ の円に内在する観測点の値のみ(5)式に適 用した。

以上の考察より推定した地下水位と観測水位を図-6 に示す. 解析で求めた推定地下水位と観測地下水位は概 ね一致し, 再現性を有していると判断した.

次に, 推定地下水位と地下水流動解析により推定した 地下水流量ベクトルの比較結果を図-7に示す. 地下水流 量ベクトルは, 推定地下水位コンターに対して直交し, 北東および北西方向から美々川およびウトナイ湖に流入 することが認められる.

ここで, 地下水流動解析において推定した透水係数 $k$ の妥当性を検証する. 透水係数 $k$ の算定は, 推定地下水 
表-3 現地試験值と計算値の透水係数比較 4

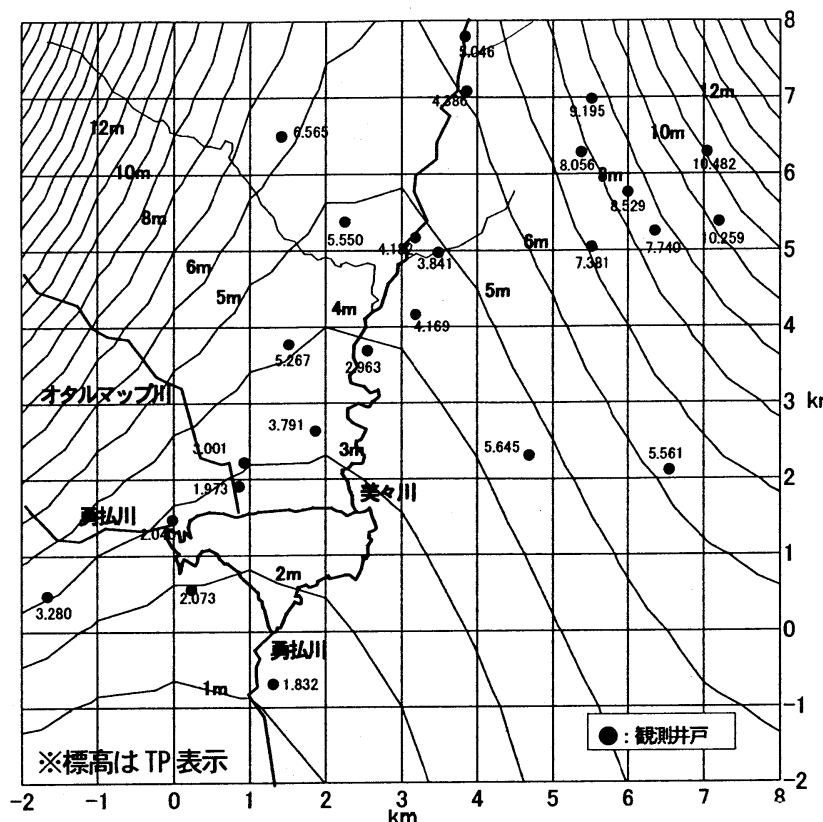

図-6＼cjkstart観測水位と解析地下水位コンター (TP)

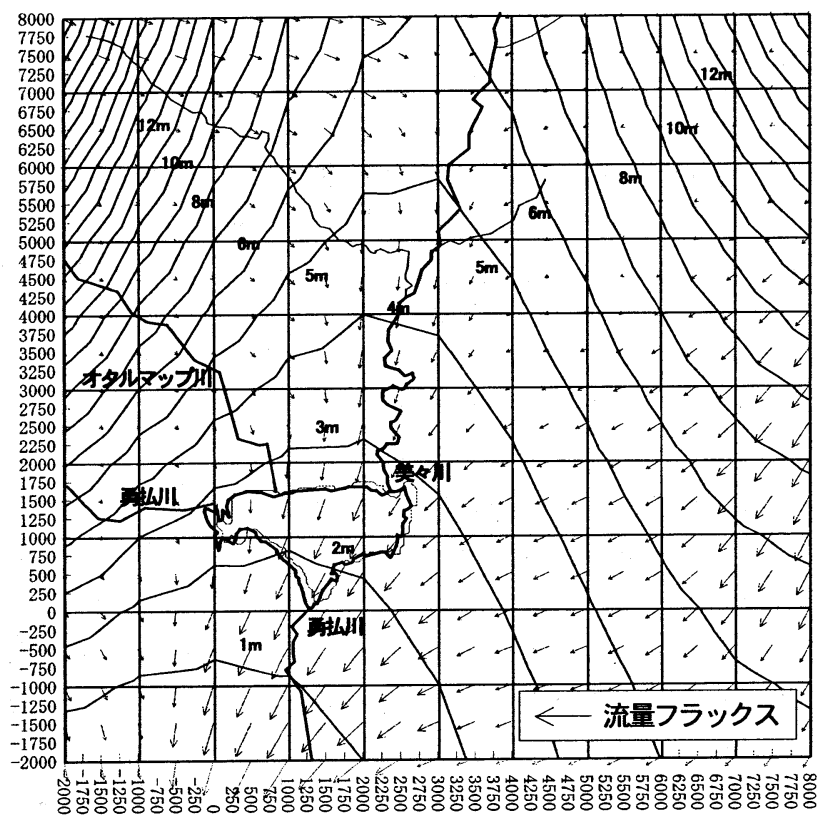

図-7 推定地下水位と地下水流量フラックスの比較

位 $h$ と不透水層面から帯水層厚 $B$ を求め, 透水量俰数 $T$ を帯水層厚 $B$ で除すことで求めた. 本モデルで推定した 透水係数と美々川流域における代表的な構成地質の現地 試験結果資料 ${ }^{4)}$ との比較を表-3に示す. 現地試験結果は, 帯水層では $5 \times 10^{-1} \sim 2 \times 10^{-4} \mathrm{~cm} / \mathrm{s}$ の範囲を示し, 低透水層, 難透水層では $6 \times 10^{-5} \sim 10^{-6} \mathrm{~cm} / \mathrm{s}$ の範囲を示す. 帯水層を 対象とした計算値は, $1 \times 10^{-2} \sim 5 \times 10^{-2} \mathrm{~cm} / \mathrm{s}$ にあり, 現 地試験結果の範囲に収まることから透水係数の值は正確 に推定されているといえる.

\begin{tabular}{|l|l|l|c|}
\hline \multicolumn{2}{|c|}{ 条 件 } & 透水係数 $k(\mathrm{~cm} / \mathrm{s})$ & 地質区分 \\
\hline \multirow{4}{*}{$\begin{array}{l}\text { 現地試験 } \\
\text { 結果 }\end{array}$} & 構成地質 $\mathrm{Spfl}_{1-3}$ & $2 \times 10^{4} \sim 1 \times 10^{-3}$ & 帯水層 \\
\cline { 2 - 4 } & 構成地質 $\mathrm{Spfa}_{1,2}$ & $5 \times 10^{-1}$ & 帯水層 \\
\cline { 2 - 4 } & 構成地質 $\mathrm{Spfl}_{7-10}$ & $7 \times 10^{-2}$ & 帯水層 \\
\cline { 2 - 4 } & 構成地質 $\mathrm{B}_{\mathrm{BC}}$ & $6 \times 10^{-5}$ & 低透水首 \\
\cline { 2 - 4 } & 構成地質 $\mathrm{F}_{\mathrm{M}}$ & $1 \times 10^{-6}$ & 難透水層 \\
\hline 計算值 & & $1 \times 10^{-2} \sim 5 \times 10^{-2}$ & 帯水層 \\
\hline
\end{tabular}

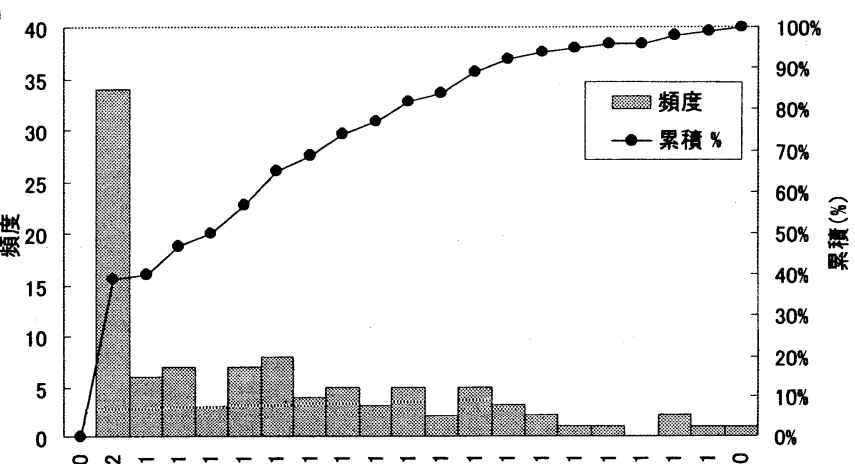

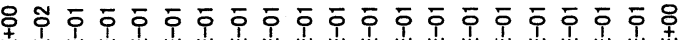

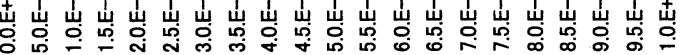
透水係数 $k(\mathrm{~cm} / \mathrm{s})$ の階級

\section{図-8＼cjkstart透水係数推定値のヒストグラム}

表-4 再現計算条件

\begin{tabular}{|c|l|}
\hline 項目 & \multicolumn{1}{|c|}{ 計算条件 } \\
\hline 計算期間 & 平成 12 年8月 17 日 23 日の6日間 \\
\hline 流入河川 & 勇払川 $0.08 \mathrm{~m}^{2} / \mathrm{s}$ \\
\cline { 2 - 2 } & 美々川 $0.14 \mathrm{~m}^{2} / \mathrm{s}$ \\
\cline { 2 - 3 } & オタルマップ川 $0.01 \mathrm{~m}^{2} / \mathrm{s}$ \\
\hline 流出河川 & 勇払川 $0.22 \mathrm{~m}^{2} / \mathrm{s}$ \\
\hline 地下水 & 流入流出を考慮 \\
\hline 風 & 毎正時観測風向風速 \\
\hline 平均水位 & 期間平均水位 $2.04 \mathrm{~m}$ \\
\hline
\end{tabular}

\section{4. ウトナイ湖流再現計算}

本研究において構築した湖流解析モデルは, 平水時で の時系列変化が小さい河川流量, 地下水流量及びウトナ イ湖水位を定常条件として解析を行った. 一方, 風向風 速は，毎正時の観測風向·風速値を 1 時間おきに変化させ, 湖流解析を実施した. 解析結果の妥当性は，実績観測結 果との比較により検証を行った.

再現計算の対象期間は，降雨による出水時を除く平成 12 年 8 月 17 日〜23 日を対象とした. 河川流量は平成 12 年 8 月 12 日に 4 回観測が行なわれており, 平均観測流量 として与えた. 風はウトナイ湖岸に設置した風向風速計 の毎正時観測風向風速值を与えた. 湖内の流向流速計の 設置地点は図- 9 のとおり，5 地点で観測が行なわれてい る. 観測結果によれば, No1,No2,No4,No5 の地点は, 河 川流入の影響が大きいが，流向・流速の変化は小さい. 


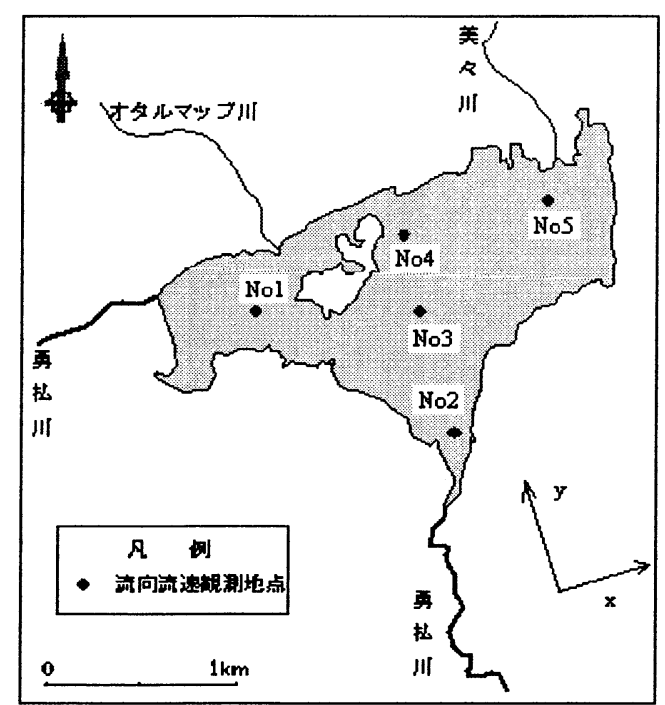

図-9 流向流速計設置地点

表-5 再現期間内平均流速比較

\begin{tabular}{|c|c|c|c|c|c|}
\hline & No1 & No2 & No3 & No4 & No5 \\
\hline 観測流速 $(\mathrm{m} / \mathrm{s})$ & 0.005 & 0.055 & 0.010 & 0.021 & 0.018 \\
計算流速 $(\mathrm{m} / \mathrm{s})$ & 0.011 & 0.059 & 0.006 & 0.012 & 0.006 \\
\hline
\end{tabular}
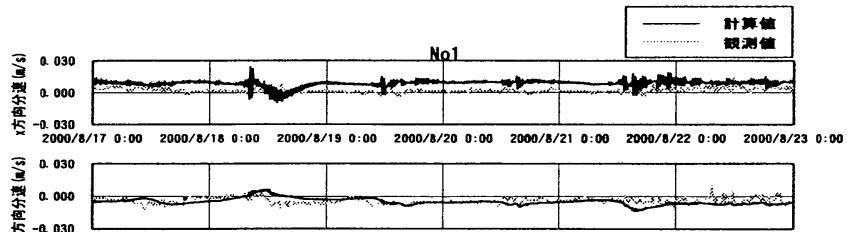

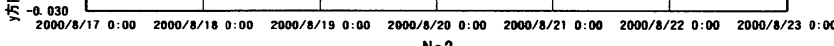
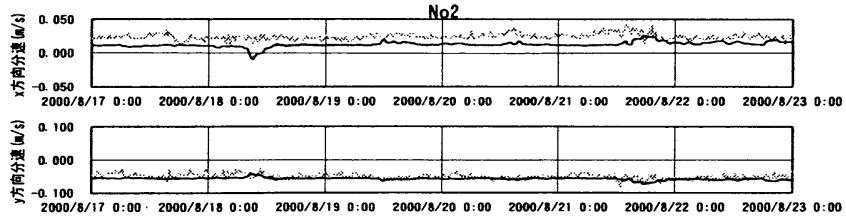

\begin{tabular}{c|ccc} 
& \\
\hline & & No3 \\
\hline
\end{tabular}
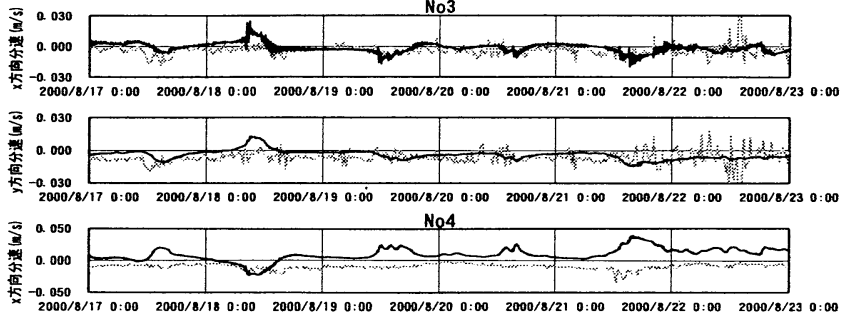

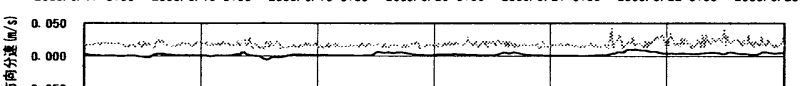

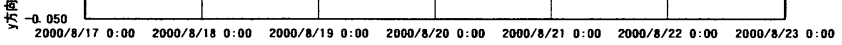

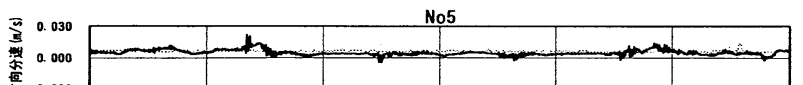

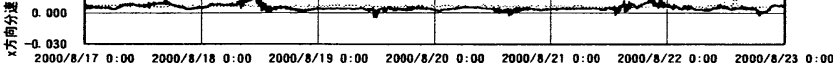

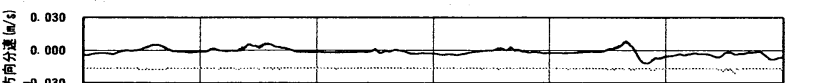

図-10 湖内観測点の流向流速再現図

また，ウトナイ湖中央部に設置された No3の地点は，風 の影響を遮断する施設が無いため流向・流速の変化は, 大きくなっている. 計算条件を表-4に示す. 湖流解析の 基礎式は，流速成分を平面的にとらえ水面変動による圧 力差を考慮可能な 2 次元非線形長波方程式を採用した.
表-6 予測計算条件

\begin{tabular}{|c|l|}
\hline 項目 & \multicolumn{1}{|c|}{ 計算条件 } \\
\hline 計算期間 & 30 日間 \\
\hline$\Delta \mathrm{t}$ & $4 \mathrm{sec}$ \\
\hline 流入河川 & 勇払川 $0.08 \mathrm{~m}^{2} / \mathrm{s}$ \\
& 美々川 $0.14 \mathrm{~m}^{2} / \mathrm{s}$ \\
\cline { 2 - 2 } & オタルマップ川 $0.01 \mathrm{~m}^{2} / \mathrm{s}$ \\
\hline 流出河川 & 勇扎川 $0.22 \mathrm{~m}^{2} / \mathrm{s}$ \\
\hline 地下水 & 流入流出を考慮 \\
\hline 風 & 毎正時の卓越風向 30 日間繰り返し \\
\hline 平均水位 & $2.04 \mathrm{~m}$ \\
\hline トレーサ & 美々川流入部に連続注入 \\
\hline 拡散倸数 & $0.1 \mathrm{~m}^{2} / \mathrm{s}$ \\
\hline
\end{tabular}

計算メッシュ間隔は $25 \mathrm{~m}$ とする.

再現計算では, これら 5 地点の観測データに基づき, 湖床粗度係数や風の水面摩擦係数などのパラメー夕同定 を行うが, 特にNo3 の地点は, 風の影響が湖流に反映さ れているため, 重視してパラメータの同定を行った. 表 -5に示す再現計算結果は, 平均流速に関し概和一致した と考えている. しかしながら，図-10 に示す流向変動成 分は，十分な再現精度を有していない地点が存在する. 特に No4 は, 流向成分が反対の傾向を示しており，その 原因として観測点左側に位置する浅水部分の影響を適切 に表現出来なかったためと考えている.

\section{5. ウトナイ湖の水質拡散予測シミュレーション}

污染物質の滞留・拡散特性を把握することを目的とし， 地下水流入出及び海陸風を外的条件による，予測シミュ レーションを行った. 海陸風は, 近隣の苫小牧測候所に おける毎正時の最多風向を 30 日間繰り返し与えた.

なお，表-6に示すとおり，流入・流出河川の流量及び 地下水, 湖内の水位に関しては, 前述の再現計算条件を 使用した. 計算結果を図-11, 12 に示す. 図-13,14 は計 算開始 30 日目の湖流及びトレーサの滞留・抎散状況を示 している. ウトナイ湖における水質拡散シミュレーショ ンを行った結果, 美々川の流入部から投入したトレーサ はゆっくりと南下し, 湖南側の勇払川へ流出していく傾 向にあるが，風の変化に伴い湖流も変動するため，一部 が湖の中央部で発生する環流に捉えられ滞留し, 濃度が 高くなる結果となった.

\section{6. おわりに}

本研究は, 地下水流動を境界条件に取り入れた浅水湖 を対象とした水質拡散モデル開発のために行った. 解析 上重要な要因となる湖周辺の地下水流動解析モデルには, 


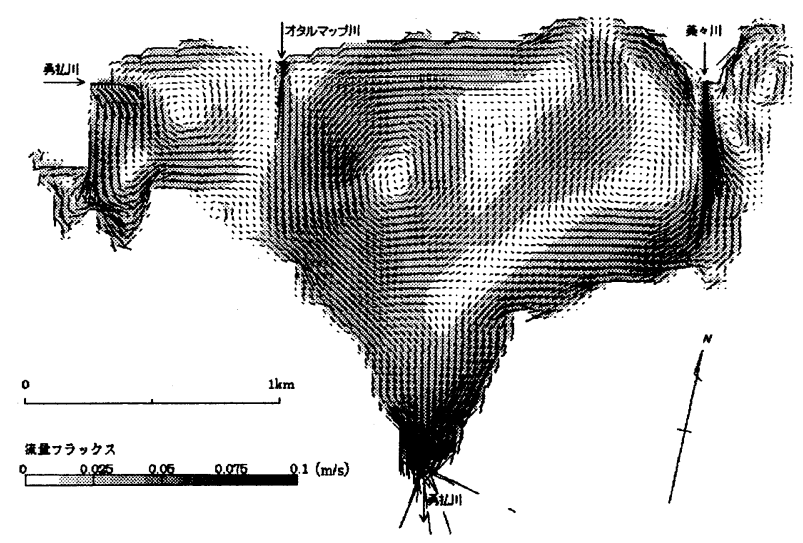

図-11 流向流速結果 30 日目 6 時時点

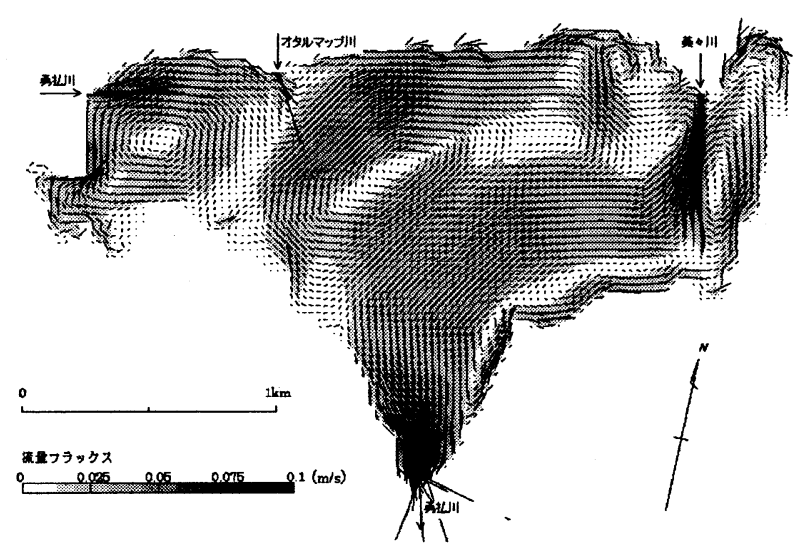

図-12 流向流速結果 30 日目 18 時時点

バリオグラム理論を適用するとともに，解析により得ら れた推定透水係数は実測値とほぼ一致し, 高い適用性で あることを実証した. また, 地下水流動を考慮したウト ナイ湖流解析モデルを用い, 平成 12 年 8 月の湖流ベクト ルについて実測值と比較した結果，平均流速については 概ね一致した. さらに，水質拡散現象を再現するモデル については, 湖北側に位置する美々川からトレ一サを注 入し，その濃度分布域を確認したが, 湖東側に南下する 流れに伴われ高い濃度を有する区域がみられた。 さらに 湖中央部には風向変化に伴い環流が生じ，トレーサがこ の環流に補足され比較的濃度の高い部分が発生した.こ れらは, 観測結果による濃度の高い分布域とも比較的一 致する結果となった.

今後, 時間的な変化についても追従可能なモデルを開 発することでウトナイ湖の水質拡散定量評価モデルの構 築が可能であると考えている. また，污濁源対策や樹林 帯による水質改善対策について評価を行うとともにサロ ベツ湿原や釧路湿原についても解析する予定である.

謝辞 : 本研究を行うにあたり, ウトナイ湖周辺の地下水 位デー夕を提供して頂いた国土交通省北海道開発局石狩 川開発建設部千歳川河川事務所の関係各位に対し，ここ に記して謝意を表します。

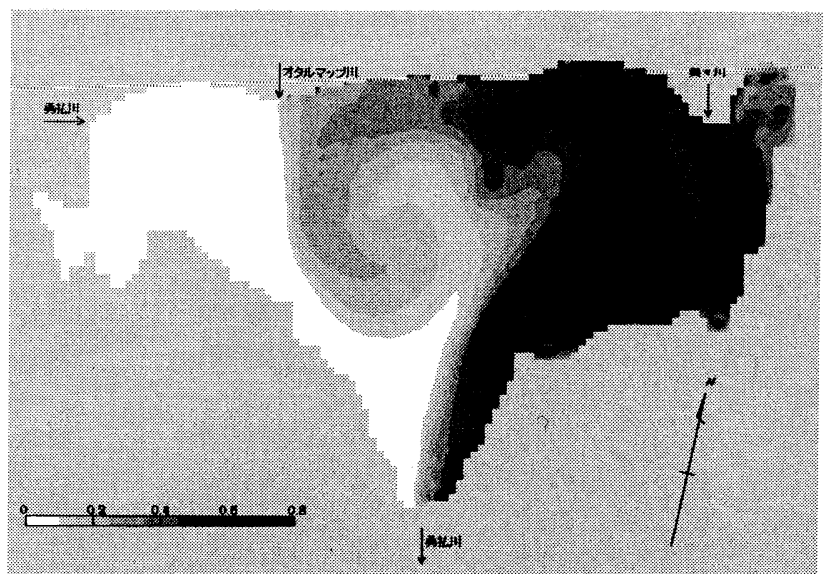

図-13 トレーサ濃度（注入 30 日目 6 時時点）

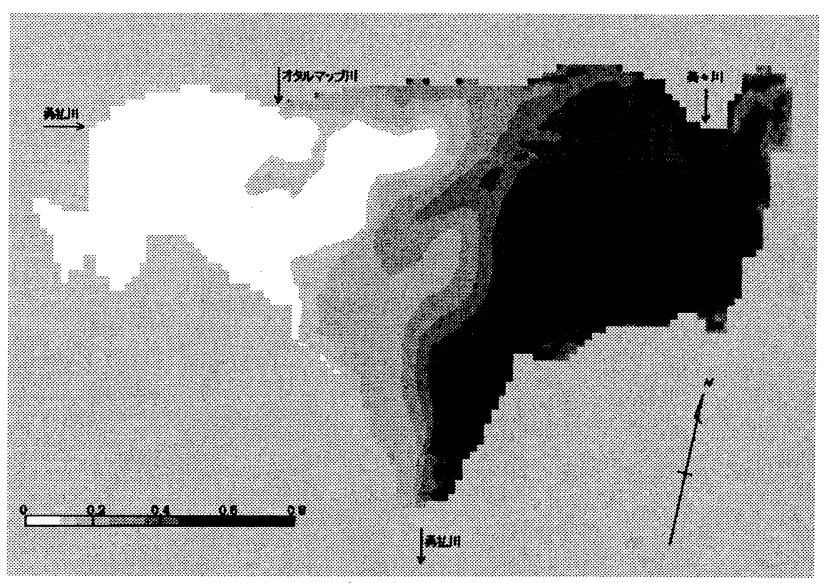

図-14 トレーサ濃度（注入 30 日目 18 時時点）

\section{参考文献}

1)長谷川覚也, 長谷川裕史, 藤間聡 : 地下水流動解析を含むウ トナイ湖水拡散モデルについて, 水工学論文集, 第 47 号, pp.1207-1212, 2003.

2)Delhomme, J. P. : Kriging in the Hydrosciences, Advances in Water sesorces, vol.1, No.5, pp.251-266, 1978.

3)T.R.マッカーラ, 三浦功, 田尾陽一: 計算機のための数値計算 法概論, pp.225-231, 1972.

4)千歳川放水路地下水工法調査委員会報告書, pp.21, 2001. 5)一松信, 戸川隼人：数值解析における誤差, pp.113-125. 1975. 6)藤間峪, 中田満洋 : 空間分布構造を有する透水係数の統計的 推定法, 日本地下水学会会誌, 第 28 巻, 第 1 号, pp.15-24, 1986. 7)和田麻衣子, 藤間聡 : 不均質帯水層における地下水パラメー 夕の推定に関する研究, 土木学会北海道支部論文報告集, pp.254-259, 2000.

8)岩佐義朗著 : 湖沼工学, 山海堂, pp118-122, 1990.

9)Ghislain de Marsily : Quantitative Hydrogeology, ACADEMIC PRESS, pp.284-337, 1986.

10)C.A.Brebbia : APPLIED NUMERICAL MODELLING ENTECH PRESS LONDON PLYMOUTH, pp.125-130, 1978

(2003年 9 月 30 日受付) 